\title{
Assessment of Microbial Biomass Carbon and Nitrogen in Some Tea Soils of Bangladesh
}

\author{
SMAbdur Rahman and ARM Solaiman \\ Department of Soil Science, Bangabandhu Sheikh Mujibur Rahman Agricultural University (BSMRAU), Salna, Gazipur 1706, Bangladesh
}

[Received 04 December 2007; Accepted 14 June 2008]

\begin{abstract}
Microbial biomass carbon $(\mathrm{C})$ and nitrogen $(\mathrm{N})$ and their contribution to soil organic carbon and total $\mathrm{N}$ contents were assessed in soils collected from Bilashchara Tea Estate under Bangladesh Tea Research Institute (BTRI), Srimangal of Moulavibazar district, and Sripur Tea Garden under Jaintapur of Sylhet district. Microbial biomass $C$ and $\mathrm{N}$ in Bila shchara Tea Estate soils varied from 90.4-144.0 and 20.5-29.0 mg/kg soil, and that of Sripur Tea Garden soils varied from $120.7-362.0$ and $26.6-59.5 \mathrm{mg} / \mathrm{kg}$ soil, respectively. Within the two tea growing areas biomass $\mathrm{C} / \mathrm{N}$ ratios ranged from 3.35-6.12. Relationships between biomass $\mathrm{C}$ and organic carbon and biomass $\mathrm{N}$ and total $\mathrm{N}$ were positively correlated. The contribution of biomass $\mathrm{C}$ to soil organic $\mathrm{C}$ was $1.23 \%$, ranging from $0.9-1.55 \%$ and the contribution of biomass $\mathrm{N}$ to total $\mathrm{N}$ content of the soils ranged from $1.19-2.89 \%$.
\end{abstract}

Keywords: Biomass carbon (C), Biomass nitrogen (N), Organic C, Total N, Tea soil

\section{Introduction}

Population of heterotrophic soil microorganisms play a major role in the decomposition of organic materials applied to the soil. The decomposed materials are used as carbon source by the microbes for the multiplication of their cell number or increase their population. A part of the microbial population used to die regularly due to the changes of the environmental condition ${ }^{1}$. These dead cells can be easily decomposed and mineralized by the microorganisms that survived ${ }^{2-4}$ and they contribute a considerable amount of nutrients for the growing plants $^{5-6}$.

Crop productivity of soil depends mainly on its fertility status, i.e., the amount of available nutrients in soil. These available plant nutrients that reflect soil fertility are mostly derived from the soil microbial biomass. Microbial biomass can be used for monitoring soil fertility and soil pollution. In most soils, the living organisms (microbial biomass) make up about 1-3\% of total soil organic matter ${ }^{7}$. Although microbial biomass represents a small fraction of the total soil organic matter, it has a relatively rapid turn over and nutrient cycling, both through the oxidation of soil organic matter and a labile reservoir of nutrient elements such as $\mathrm{C}, \mathrm{N}, \mathrm{P}$ and $\mathrm{S}^{5,8}$. Marumoto ${ }^{9}$ reported that about 6.65 and $34 \%$ of $\mathrm{N}$ mineralized were obtained from the freshly killed biomass and from non-biomass organic matter of paddy soil respectively. Thus, $\mathrm{N}$ held in the microbial biomass is much more labile than other soil fractions. Arable soils contain 30-150 kg N/ha in the plough layer. Grassland contains considerably more ${ }^{7}$.
In order to estimate the microbial biomass content and to quantify the amount of available plant nutrients derived from microbial biomass in Bangladesh soils, biomass $\mathrm{C}$ and biomass $\mathrm{N}$ were measured by applying the chloroform fumigation and dryingrewetting methods. The contribution of biomass $\mathrm{C}$ to soil organic carbon was $2 \%$, ranging from $1.35-3.52 \%$. The contribution of biomass $\mathrm{N}$ to total soil $\mathrm{N}$ ranged from 1.15-2.95\% (average 2.11\%). In acid soil, the method failed to estimate the microbial biomass, not because bacterial growth was inhibited after fumigation but because labile $\mathrm{C}$ source was taken up which was different from the killed biomass $\mathrm{C}^{10}$. The turn over rate of soil organic matter in tropical soil is higher due to favourable soil temperature and other environmental factor. However, information on the contribution of soil microbial biomass in supplying plant nutrients to acid soil is very limited in our agro-climatic conditions.

The objective of our study was to estimate the microbial biomass $\mathrm{C}$ and $\mathrm{N}$ and their contribution to soil organic carbon and total nitrogen contents of some selected tea soils of Bangladesh.

\section{Materials and Methods}

Collection of soil samples and their initial properties

Soils of Bilashchara Tea Estate under Bangladesh Tea Research Institute (BTRI), Srimangal, Moulavibazar district and that of Sripur Tea Garden under Jaintapur upazila, Sylhet district used in this experiment belong to Low Hills and Piedmont Plains (agroecological zone, AEZ 29). Soil samples were collected during winter

*Corresponding author:

Dr. ARM Solaiman, Professor, Department of Soil Science, Bangabandhu Sheikh Mujibur Rahman Agricultural University (BSMRAU), Salna, Gazipur 1706, Bangladesh Tel (Office): (02) 9205310-14, Ext 2040; Tel (Home): (02) 9342649; Cell: 01552 495381; Fax: +880 (02) 9205310; E-mail: arm_solaiman@yahoo.com 
season. Three sections from Bilashchara Tea Estate and one section from Sripur Tea Garden were chosen for sample collection. Each section consisted of 'tillah'. From each section soil samples were collected from top, middle and bottom of the tillah. The depth of the collected soil samples was between 0-9 inches. In total 12 soil samples were collected from four tillah/sections. Each soil sample was a composite of three soil samples. The bulk soil samples were air-dried, crushed and passed through two mm sieve and analyzed for characterization. All undesirable materials like roots, insects, stones and discrete pieces of organic matter were cleaned. Initial properties of the soils are shown in Table 1.

Table 1. Initial properties of soil of different tea estates

\begin{tabular}{|c|c|c|c|c|}
\hline Soil sample & $\begin{array}{l}\text { Soil } \\
\mathrm{pH}\end{array}$ & $\begin{array}{c}\text { Organic } \\
\text { carbon } \\
(\%)\end{array}$ & $\begin{array}{c}\text { Organic } \\
\text { matter } \\
(\%)\end{array}$ & $\begin{array}{c}\text { Total } \\
\text { nitrogen } \\
(\%)\end{array}$ \\
\hline \multicolumn{5}{|l|}{ Bilashchara Tea Estate } \\
\hline Section 9: Top & 4.45 & 1.3116 & 2.2690 & 0.1262 \\
\hline \multicolumn{5}{|l|}{ Bilashchara Tea Estate } \\
\hline Section 9: Middle & 4.25 & 1.0632 & 1.8390 & 0.1134 \\
\hline \multicolumn{5}{|l|}{ Bilashchara Tea Estate } \\
\hline Section 9: Bottom & 4.30 & 1.0938 & 1.8920 & 0.1129 \\
\hline \multicolumn{5}{|l|}{ Bilashchara Tea Estate } \\
\hline Section 7: Top & 4.50 & 0.9330 & 1.6140 & 0.1107 \\
\hline \multicolumn{5}{|l|}{ Bilashchara Tea Estate } \\
\hline Section 7: Middle & 4.50 & 0.9156 & 1.5839 & 0.1187 \\
\hline \multicolumn{5}{|l|}{ Bilashchara Tea Estate } \\
\hline Section 7: Bottom & 4.25 & 1.0398 & 1.7988 & 0.0952 \\
\hline \multicolumn{5}{|l|}{ Bilashchara Tea Estate } \\
\hline Section 5: Top & 4.20 & 1.1882 & 2.0555 & 0.2010 \\
\hline \multicolumn{5}{|l|}{ Bilashchara Tea Estate } \\
\hline Section 5: Middle & 4.25 & 0.9918 & 1.7158 & 0.1398 \\
\hline \multicolumn{5}{|l|}{ Bilashchara Tea Estate } \\
\hline Section 5: Bottom & 4.30 & 0.9912 & 1.7147 & 0.1327 \\
\hline Sripur: Top & 4.25 & 0.9912 & 1.7147 & 0.1453 \\
\hline Sripur: Middle & 4.40 & 1.2402 & 2.1455 & 0.1311 \\
\hline Sripur: Bottom & 4.30 & 3.077 & 5.3232 & 0.499 \\
\hline
\end{tabular}

\section{Soil fumigation}

Soil fumigation was done with alcohol free chloroform. Usually $\mathrm{CHCl}_{3}$ contains some amount of alcohol that retards the fumigation process. To remove alcohol, $100 \mathrm{ml}$ chloroform and $200 \mathrm{ml} \mathrm{5 \%}$ $\mathrm{H}_{2} \mathrm{SO}_{4}$ (1:2) was taken in a separatory funnel and was shaken thoroughly by hand for at least 20 times. Alcohol free chloroform was collected in a beaker from separatory funnel and the process was repeated four times with $5 \% \mathrm{H}_{2} \mathrm{SO}_{4}$ and five times with distilled water. After rinsing the desiccators with boiled water, $200 \mathrm{ml}$ boiled water was put into the desiccators and an alcohol free chloroform containing beaker $(100 \mathrm{ml})$ was also placed at the bottom of the desiccators. The conical flasks containing soil samples were placed inside the desiccators. After tightly closing, the desiccators were evacuated with a mini vacuum pump (Yamato, Hitachi, Model
No. Minivoc PD-52) at least ten minutes. The desiccators were then kept in dark for $24 \mathrm{~h}$.

\section{Measurement of biomass carbon}

Fumigated and non-fumigated soils were extracted with $0.5 \mathrm{M}$ $\mathrm{K}_{2} \mathrm{SO}_{4}$ (soil: $\mathrm{K}_{2} \mathrm{SO}_{4}$ solution = 1:4) for $30 \mathrm{~min}$ and filtrated. From the extracts the amount of biomass $\mathrm{C}$ was measured according to the method described by Vance et al. ${ }^{11}$ where $10 \mathrm{ml}$ extract in 10 $\mathrm{ml}$ conical flask and $2 \mathrm{ml} 0.4 \mathrm{NK}_{2} \mathrm{Cr}_{2} \mathrm{O}_{7}, 10 \mathrm{ml}$ concentrated $\mathrm{H}_{2} \mathrm{SO}_{4}$ were added to it. After heating $\left(200^{\circ} \mathrm{C}\right.$ for $\left.30 \mathrm{~min}\right)$ in a hot plate, it was titrated with Mohr's salt. The amount of biomass C (Bc) was calculated from the equation:

$$
\text { Biomass carbon }=\text { Ec } \times 2.64
$$

Here, Titration reading of extractable carbon, En $=(F-N F) \times 0.15 \times \frac{80}{10} \times \frac{1000}{\text { soil wt. }} \mathrm{mg} / \mathrm{kg}$

Where, $\mathrm{F}$ = amount of Mohr's salt $(\mathrm{ml})$ required to titrate fumigated sample, $\mathrm{NF}=$ amount of Mohr's salt $(\mathrm{ml})$ required to titrate non fumigated sample, $80=$ volume of the soil extract $(\mathrm{ml}), 10=$ amount of soil extract used in distillation $(\mathrm{ml}), \mathrm{W}=1,000 \mathrm{mg}$ soil, $\mathrm{w}=$ amount of soil sample used, and $0.15=$ titration factor.

\section{Measurement of biomass nitrogen}

Biomass $\mathrm{N}$ was measured according to the method described by Brookes et al. ${ }^{12-13}$. Biomass $\mathrm{C}$ and $\mathrm{N}$ were measured from the same extract. Tem millilitre extract was taken in a Kjeldhal flask and $5 \mathrm{ml}$ concentrated $\mathrm{H}_{2} \mathrm{SO}_{4}, 0.5 \mathrm{ml} \mathrm{CuSO}_{4}$ and 2-3 stone were added to it. After heating in a digestion chamber for $3 \mathrm{~h}$, it was distilled with $40 \% \mathrm{NaOH}$. The $50 \mathrm{ml}$ distillate was collected in $5 \mathrm{ml}$ $2 \%$ boric acid and titrated against $0.005 \mathrm{~N} \mathrm{H}_{2} \mathrm{SO}_{4}$. The amount of Biomass N (Bn) was calculated from the equation:

$$
\text { Biomass nitrogen }=\text { En } x 1.85
$$

Here,

Titration reading of extractable nitrogen, $E n=(F-N F) \times 0.07 \times \frac{80}{10} \times \frac{1000}{\text { soil wt. }} \mathrm{mg} / \mathrm{kg}$

Where, $\mathrm{F}$ = amount of Mohr's salt (ml) required to titrate fumigated sample, $\mathrm{NF}=$ amount of Mohr's salt $(\mathrm{ml})$ required to titrate non fumigated sample, $80=$ volume of the soil extract $(\mathrm{ml}), 10=$ amount of soil extract used in distillation $(\mathrm{ml}), \mathrm{W}=1,000 \mathrm{mg}$ soil, $\mathrm{w}=$ amount of soil sample used, and $0.07=$ titration factor.

\section{Results and Discussion}

Quantity of microbial biomass carbon and nitrogen in tea soils

A quantitative measurement of microbial biomass $\mathrm{C}$ and $\mathrm{N}$ contents in Bilashchara Tea Estate soils and Sripur Tea Garden soils were done by chloroform fumigation-extraction method. Biomass $\mathrm{C} / \mathrm{N}$ ratio, \% biomass $\mathrm{C}$ in organic carbon, \% biomass $\mathrm{N}$ in total nitrogen and nitrogen concentration in biomass were calculated from the results of total biomass $\mathrm{C}$ and $\mathrm{N}$ (Table 2). Microbial biomass $\mathrm{C}$ and $\mathrm{N}$ in Bilashchara Tea Estate soils varied from $90.4-144.0 \mathrm{mg} / \mathrm{kg}$ soil and 20.5-31.5.0 mg/ kg soil respectively. Furthermore, microbial biomass $C$ and N in Sripur Tea Garden soils varied from 120.7-362.0 $\mathrm{mg} / \mathrm{kg}$ soil and 26.6-59.5 mg/kg soil, respectively. 
Table 2. Microbial biomass carbon and nitrogen concentration and their relative ratios as a percentage of organic carbon and total nitrogen in soils

\begin{tabular}{|c|c|c|c|c|c|c|}
\hline Soil sample & $\begin{array}{c}\text { Bc } \\
\text { (mg/kg soil) }\end{array}$ & $\begin{array}{c}\text { Bn } \\
\text { (mg/kg soil) }\end{array}$ & $\begin{array}{c}\mathrm{Bc} / \mathrm{Bn} \\
\text { ratio }\end{array}$ & $\begin{array}{c}\mathrm{Bc} / \mathrm{OC} \\
(\%)\end{array}$ & $\begin{array}{c}\mathrm{Bn} / \mathrm{TN} \\
(\%)\end{array}$ & $\begin{array}{l}\mathrm{N} \text { concentration } \\
\text { in biomass }(\%)\end{array}$ \\
\hline \multicolumn{7}{|l|}{ Bilashchara } \\
\hline Tea EstateSection 9: Top & 144.0 & 29.0 & 4.97 & 1.09 & 2.29 & 10.07 \\
\hline \multicolumn{7}{|l|}{ Bilashchara Tea Estate } \\
\hline Section 9: Middle & 115.2 & 24.5 & 4.70 & 1.08 & 2.16 & 10.63 \\
\hline \multicolumn{7}{|l|}{ Bilashchara Tea Estate } \\
\hline Section 9: Bottom & 129.6 & 26.0 & 4.98 & 1.18 & 2.30 & 10.03 \\
\hline \multicolumn{7}{|l|}{ Bilashchara Tea Estate } \\
\hline Section 7: Top & 108.0 & 23.0 & 4.69 & 1.16 & 2.07 & 10.64 \\
\hline \multicolumn{7}{|l|}{ Bilashchara Tea Estate } \\
\hline Section 7: Middle & 105.0 & 20.5 & 5.12 & 1.15 & 1.72 & 9.76 \\
\hline \multicolumn{7}{|l|}{ Bilashchara Tea Estate } \\
\hline Section 7: Bottom & 122.4 & 24.3 & 5.03 & 1.17 & 2.55 & 9.92 \\
\hline \multicolumn{7}{|l|}{ Bilashchara Tea Estate } \\
\hline Section 5: Top & 118.0 & 28.6 & 4.12 & 0.99 & 1.42 & 12.1 \\
\hline \multicolumn{7}{|l|}{ Bilashchara Tea Estate } \\
\hline Section 5: Middle & 90.4 & 25.3 & 3.57 & 0.90 & 1.80 & 13.99 \\
\hline \multicolumn{7}{|l|}{ Bilashchara Tea Estate } \\
\hline Section 5: Bottom & 105.6 & 31.5 & 3.35 & 1.06 & 2.37 & 14.91 \\
\hline Sripur: Top & 120.7 & 26.6 & 4.53 & 1.21 & 1.83 & 11.01 \\
\hline Sripur: Middle & 192.7 & 38.0 & 5.06 & 1.55 & 2.89 & 9.85 \\
\hline Sripur: Bottom & 362.0 & 59.5 & 6.12 & 1.17 & 1.19 & 11.2 \\
\hline
\end{tabular}

$\mathrm{Bc}=$ Biomass carbon; $\mathrm{Bn}=$ Biomass nitrogen; $\mathrm{OC}=$ Organic carbon; $\mathrm{TN}=$ Total nitrogen; $\mathrm{N}=$ Nitrogen

Biomass C and N measured in the Sripur Tea Garden soils were comparatively higher than those in Bilashchara Tea Estate soils (Figure 1 and 2). The highest amounts of biomass C (362 mg/kg soil) and biomass $\mathrm{N}$ ( $59.5 \mathrm{mg} / \mathrm{kg}$ soil) were observed in the bottom soils of the tillah of Sripur Tea Garden (Table 2). In contrast, the lowest amounts of biomass C ( $90.4 \mathrm{mg} / \mathrm{kg}$ soil) and biomass $\mathrm{N}$ ( $20.5 \mathrm{mg} / \mathrm{kg}$ soil) were observed in the middle portion of the tillah of section 5 and section 7, respectively of Bilashchara Tea Estate (Table 2).

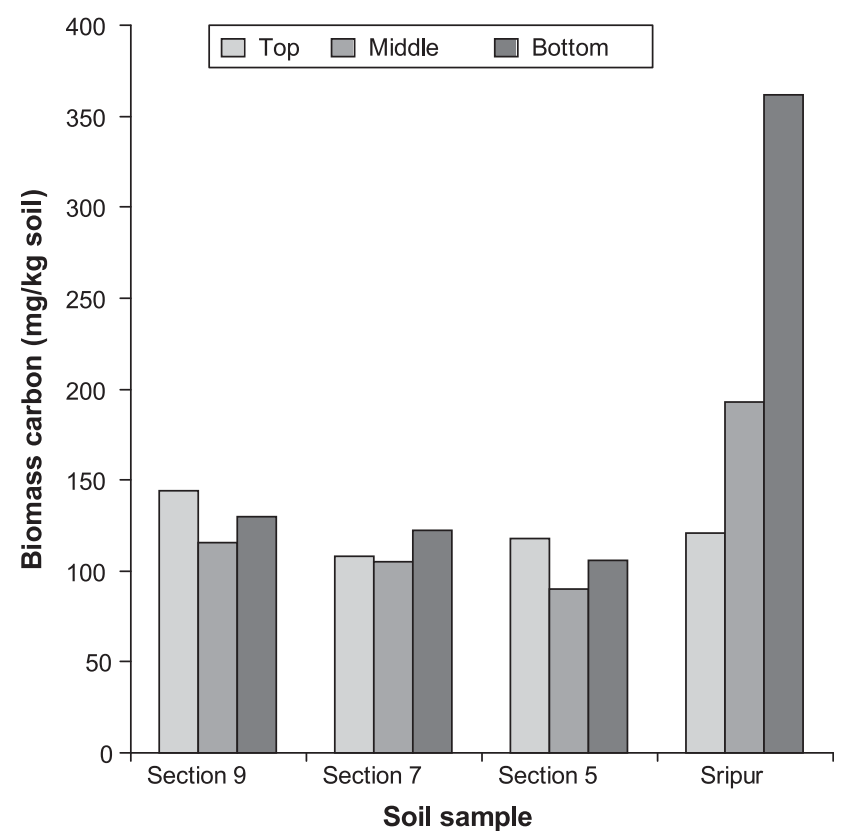

Figure 1. Biomass carbon of Bilashchara Tea Estate and Sripur Tea Garden soils.

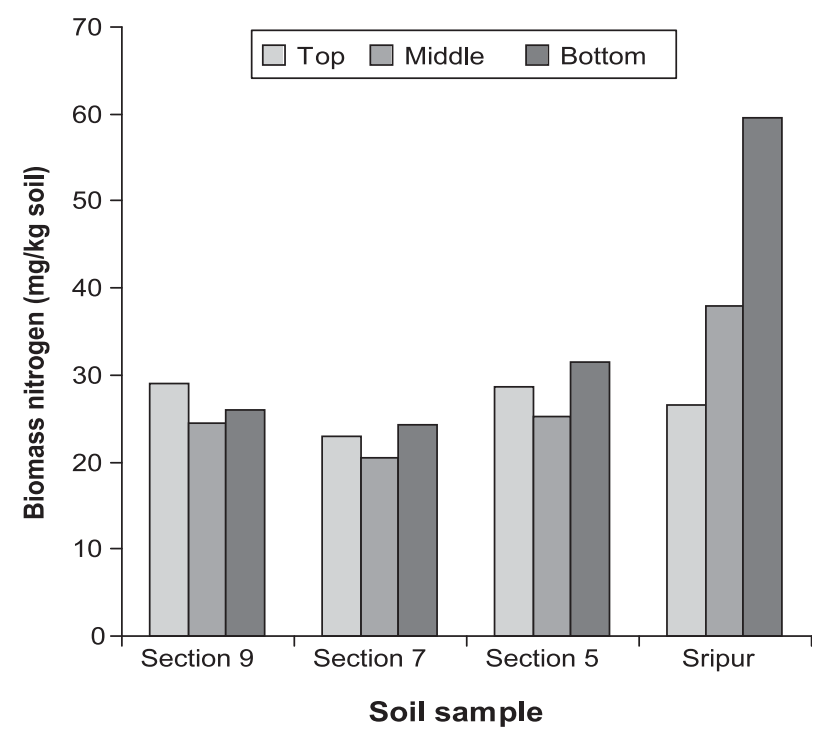

Figure 2. Biomass nitrogen of Bilashchara Tea Estate and Sripur Tea Garden soils.

High biomass content in Sripur Tea Garden soils might be due to the presence of high organic carbon (0.99-3.07\%) (Table 2) as microbial biomass formation in soil depends on organic carbon content of soil. Microbial biomass content of the Bilashchara Tea Estate soils was poor because of the low organic carbon content (0.91-1.3\%) in experimental soil (Table 2). Similar amount of microbial biomass was also found in low land paddy soil of BRRI farm, Gazipur ${ }^{14}$. Haider et al. ${ }^{8}$ also reported that microbial biomass contents in Bangladesh soils were significantly lower than those in the temperate region soils. From the report of Haider et al. ${ }^{8}$ and Howlader ${ }^{14}$ it may be concluded that, microbial biomass content 
in Sripur tea estate soils was quite higher than the other soils of Bangladesh.

\section{Biomass carbon and nitrogen ratio}

Biomass $\mathrm{C} / \mathrm{N}$ ratio varied from 3.35-6.12 considering both Bilashchara Tea Estate and Sripur Tea Garden soils (Table 2). Similar C/N ratio of microbial biomass was also found by Howlader $^{14}$ (1999) in paddy soil of BRRI farm. Haider et al. ${ }^{8}$ measured microbial biomass $\mathrm{C}$ and $\mathrm{N}$ from eight soils of Bangladesh and found wide $\mathrm{C} / \mathrm{N}$ ratio (ranged from 4.37-19.13).

Relationship between soil organic carbon and biomass carbon Figure 3 shows that the relationship between biomass $\mathrm{C}$ and soil organic carbon was positively correlated and their relationship was highly significant $\left(R^{2}=0.9393\right.$ and $\left.r=0.9691\right)$. The average contribution of biomass $C$ to soil organic carbon was about $1.23 \%$ in the soil investigated, which ranged from 0.9-1.55\% (Table 2). But Haider et al. ${ }^{8}$ found higher contribution (2\%) of biomass C to organic carbon in Bangladesh soils. Chaudhury et al. ${ }^{15}$ also found an average of $2.59 \%$ contribution of biomass carbon to organic carbon in Japanese soil. Brookes et al. ${ }^{7}$ reported that biomass C made up of $1-3 \%$ of the organic carbon.

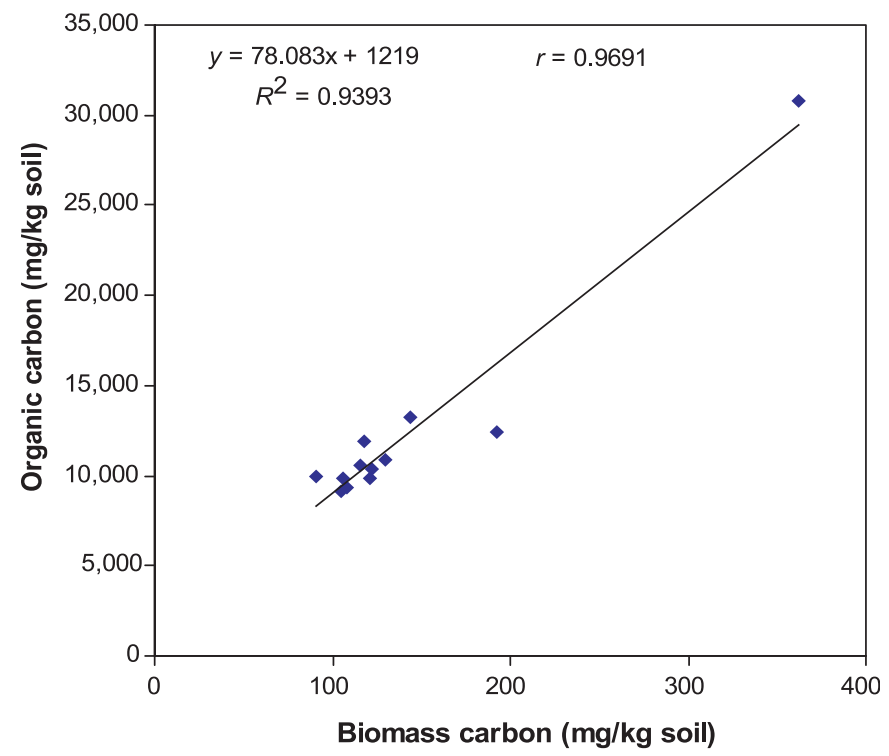

Figure 3. Relationship between biomass carbon and organic carbon.

\section{Relationship between biomass nitrogen and total nitrogen}

Figure 4 shows that the relationship between biomass $\mathrm{N}$ and total $\mathrm{N}$ in soils investigated was positively correlated $\left(R^{2}=0.7057\right.$ and $r=0.8400$ ). Similar finding was also reported by Chaudhury et al. ${ }^{15}$. Table 2 shows that the contribution of biomass $\mathrm{N}$ to the total N content of the soils ranged from 1.19-2.89\%. Similarly, Haider et al. ${ }^{8}$ showed that the contribution of biomass $\mathrm{N}$ to total $\mathrm{N}$ in some soils of Bangladesh ranged from 1.115-2.95\%. Similar results were also reported by Brookes et al. ${ }^{16}$. Assuming that dry biomass contains $50 \%$ carbon $^{17}$, the nitrogen concentration of the biomass was calculated. The concentration of nitrogen in biomass ranged from $9.76-14.91 \%$ with a mean value of $12.23 \%$ (Table 2). Chaudhury et al. ${ }^{15}$ also reported that N\% in the biomass ranged from $4.82-16.71 \%$ with a mean value of $9.86 \%$.

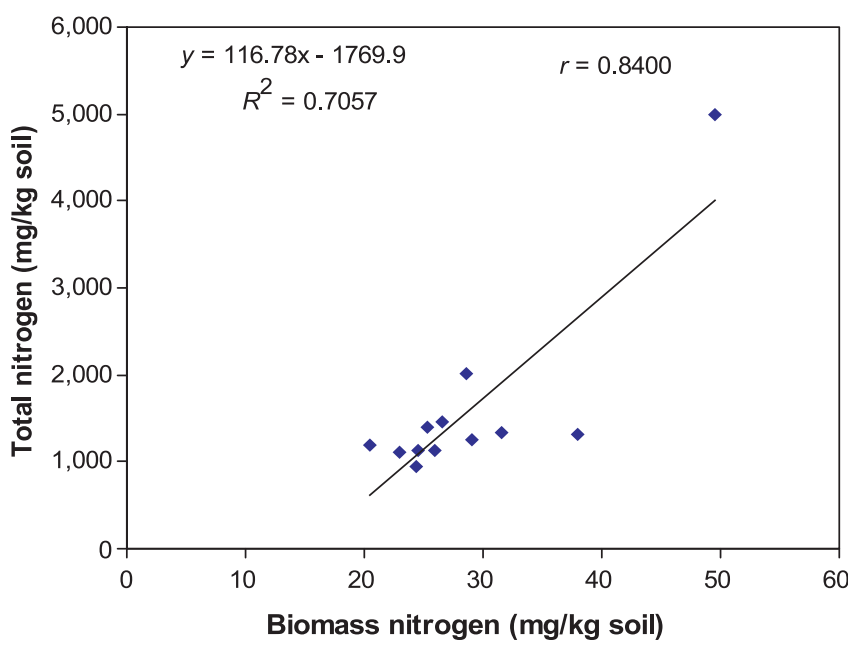

Figure 4. Relationship between biomass nitrogen and total nitrogen.

Relationship between soil organic carbon and biomass nitrogen Figure 5 shows that the relationship between biomass $\mathrm{N}$ and soil organic carbon was positively correlated $\left(R^{2}=0.7765\right.$ and $r=$ 0.8811). Chaudhury et al. ${ }^{15}$ also reported that the amount of biomass $\mathrm{N}$ positively and significantly correlated with the soil organic carbon.

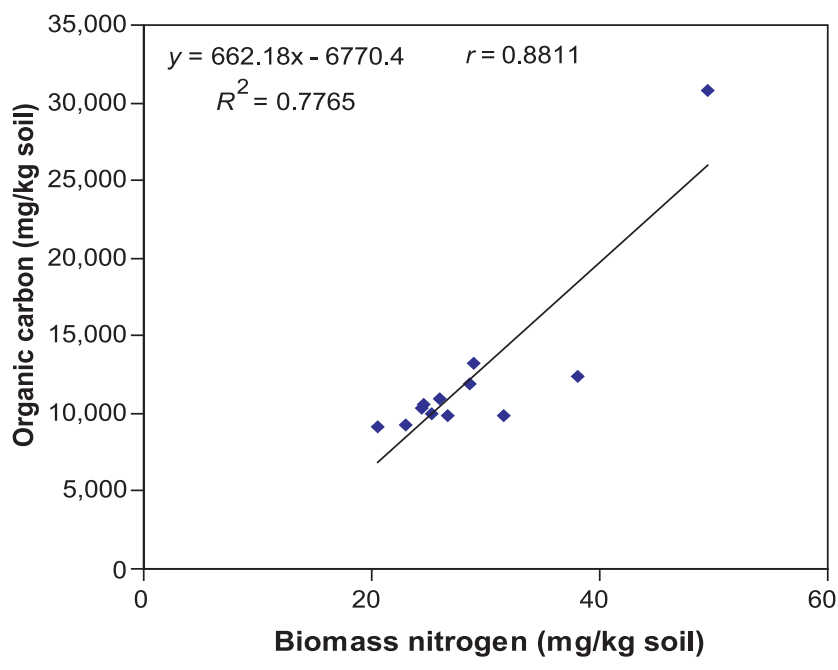

Figure 5. Relationship between organic carbon and biomass nitrogen.

\section{Relationship between biomass carbon and biomass nitrogen}

Figure 6 shows that the relationship between biomass $C$ and biomass $\mathrm{N}$ was positively correlated $\left(R^{2}=0.8468\right.$ and $\left.r=0.9202\right)$. Similar finding was also reported by many investigators ${ }^{7,15}$. 


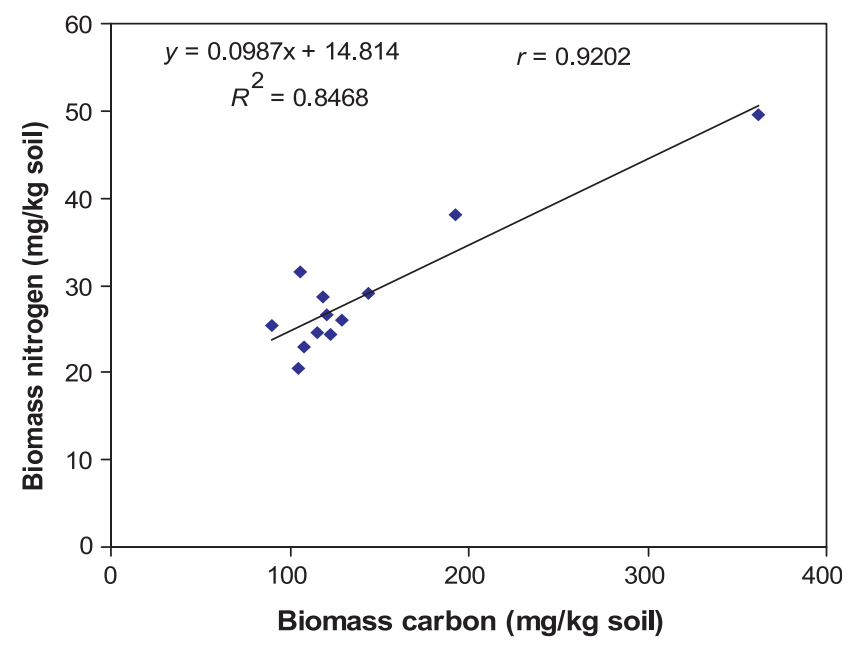

Figure 6. Relationship between biomass carbon and biomass nitrogen.

Based on the experimental results and discussion we put comments that the level of organic matter and nitrogen in most soils investigated was reasonable. But microbial biomass $\mathrm{C}$ and $\mathrm{N}$ contents were comparatively lower than the optimum level. Further, the contribution of biomass $\mathrm{C}$ to organic $\mathrm{C}$ and biomass $\mathrm{N}$ to total $\mathrm{N}$ was low. However, an optimum level of $\mathrm{N}(12.23 \%)$ was present in the microbial biomass which contributed to total $\mathrm{N}$ in soil.

\section{References}

1. Marumoto T, Anderson JPE \& Domsch KH. 1982. Decomposition of ${ }^{14} \mathrm{C}$ and ${ }^{15} \mathrm{~N}$ labelled microbial cells in soil. Soil Biol Biochem. 14: 461-467.

2. Jenkinson DS. 1976. The effects of biocidal treatments on metabolism in soil IV. The decomposition of fumigated organisms in soil. Soil Biol Biochem. 8: 203-208.

3. Anderson JPE \& Domsch KH. 1978. Minearilization of bacteria and fungi in chloroform fumigated soils. Soil Biol Bichem. 10: 207-213.

4. Nelson DW, Martin JP \& Ervin JO. 1979. Decomposition of microbial cell and components in soil and their stabilization through complexing with model humic acid type phenolic polymers. Soil Sci Soc Am J. 43: $84-88$
5. Anderson JPE \& Domsch KH. 1980. Quantities of plant nutrients in the microbial biomass of selected soils. Soil Sci. 130: 211-216.

6. Marumoto T, Anderson JPE \& Domsch KH. 1982. Mineralization of nutrients from soil microbial biomass. Soil Biol Biochem. 14: 469475.

7. Brookes PC, Ocio JA \& Wu J. 1990. The soil microbial biomass: Its measurement, properties and role in soil nitrogen and carbon dynamics following substrate incorporation. Soil Microorg. 35: 39-51.

8. Haider J, Marumoto T \& Azad AK. 1991. Estimation of microbial biomass carbon and nitrogen in Bangladesh soils. Soil Sci Plant Nutr. 37(4): 591-599.

9. Marumoto T. 1984. Mineralization of $\mathrm{C}$ and $\mathrm{N}$ from microbial biomass in paddy soil. Plant Soil. 76: 165-173.

10. Couteaux MM, Henkinet R, Pitta P, Bottner P, Billes G, Palka I \& Vannier G. 1989. Native carbon mineralization of an acid organic soil after use of the chloroform fumigation method to estimate microbial biomass. Biol Fert Soils. 8(2): 172-177.

11. Vance ED, Brookes PC \& Jenkinson DS. 1987. An extension method for measuring soil microbial biomass C. Soil Biol Biochem. 19: 703707.

12. Brookes PC, Kragit JF, Powlson DS \& Jenkinson DS. 1985. Chloroform fumigation and the release of soil nitrogen. The effects of fumigation time and temperature. Soil Biol Biochem. 17(6): 831835.

13. Brookes PC, Landsman A, Pruden G \& Jenkinson DS. 1985. Chloroform fumigation and the release of soil nitrogen. A rapid direct extraction method to measure microbial biomass nitrogen in soil. Soil Biol Biochem. 17(6): 837-840.

14. Howlader MAR. 1999. Effect of organic residues on mineralization and microbial biomass dynamics in paddy soil. MS Thesis. Bangabandhu Sheikh Mujibur Rahman Agricultural University (BSMRAU), Gazipur.

15. Chaudhury AH, Kouno K \& Ando T. 1999. Correlation among microbial biomass S, soil properties and other biomass nutrients. Soil Sci Plant Nutr. 45: 175-186.

16. Brookes PC, Powlson DS \& Jenkinson DS. 1985c. The Microbial Biomass in Soil, pp 123-125. Soils and Plant Nutrition Department, Rothamsted Experimental Station, Blackwell Scientific Publications, Oxford.

17. Brookes PC, Powlson DS \& Jenkinson DS. 1982. Measurement of microbial biomass phosphorus in soil. Soil Biol Biochem. 14: 319329. 